MH EK Balatonfüredi Kardiológiai Rehabilitációs Intézet

\title{
A mozgásprogram szerepe a kardiológiai rehabilitációban
}

\author{
Dr. Kohut László orvos ezredes, PhD
}

\begin{abstract}
Kulcsszavak: szív- és érrendszeri betegségek, kardiológiai rehabilitáció, mozgásprogram, kardiorespiratorikus fitnesz
\end{abstract}

Világszerte a vezető halálokok között szerepelnek a szív- és érrendszeri betegségek. A kardiovaszkuláris történések megelözése, a megfelelö fizikai aktivitás fenntartása, a jó életminőség biztosítása kihívást jelent a kardiológiai rehabilitáció számára. A kardiovaszkuláris rizikó csökkentésének, illetve a szív- és érrendszeri betegek hosszú távú gondozásának a leghatékonyabb módja a szekunder prevenció. A multifaktoriális kardiológiai rehabilitáció, ezen belül az egyénre szabott mozgásprogram, létjogosultságát a szakirodalomban fellelhető bizonyítékon alapuló eredmények igazolják.

A szív- és érrendszeri betegek komplex rehabilitációs programban való részvétele, a szekunder prevención keresztül jelentősen javítja ezen betegek morbiditási és mortalitási mutatóit. A részletes szakorvosi vizsgálat, a balkamra funkció, a terhelhetőség, a kiváltható iszkémia, a ritmuszavar hajlam, a revaszkularizáció teljességének és a társbetegségek ismerete függvényében a szívbetegek alacsony, közepes vagy magas kockázati csoportba oszthatók. Mindezen tényezők ismeretében állítható össze az átfogó rehabilitációs kezelési program.

A kardiológiai rehabilitáció sarokköve a fizikai tréning program. Hatékony és átfogó rehabilitációs programot enélkül nem lehet összeállítani. A mozgásprog- ramban egyaránt helyet kap a dinamikus, az aerob testmozgás, valamint rezisztencia tréning. A testmozgás és a fizikai jólét közötti kapcsolat jól ismert a szakirodalomban, a kardiológiai rehabilitáció számos előnye a rendszeres fizikai aktivitásból is származik. A rehabilitációs klinikai vizsgálatok metaanalízise azt mutatta, hogy a rendszeres testmozgás összefüggésbe hozható az összhalálozás jelentős csökkenésével, és az ismételt miokardiális infarktusok számának csökkenésével [1].

A testmozgásnak számos egyéb potenciálisan előnyös hatása is van, beleértve az endoteliális funkció javítását, a miokardialis átáramlási rezerv javítását, a dohányzásról való leszokás elősegítését, a testsúly, a szérum lipidek és a 
vérnyomás csökkentését. A fizikai aktivitás ezen kívül csökkenti a depreszszió és a szorongás előfordulását és javítja a szívbetegek életminőségét. Számos mechanizmus felelős a fizikai tréningen alapuló rehabilitációval összefüggő csökkent halálozásért, beleértve az ateroszklerotikus, antiiszkémiás, antiaritmiás, antitrombotikus és pszichológiai hatásokat [2].

A legtöbb módszertani levél azt javasolja, hogy a tréninget legalább napi 30 percen keresztül, legalább 5 napig és lehetőség szerint naponta mérsékelt intenzitással végezzék. A tréningprotokolloknak tartalmaznia kell a tréning időtartamát, intenzitását, dinamikáját, és rezisztencia tréninget is, mivel az izomerő növelése javíthatja a betegek életminőségét. A nagy intenzitású aerob edzésprogramok a mérsékelt intenzitású edzéshez képest javították a testmozgás teljesítményét és a hemodinamikai előnyöket a stabil szívkoszorúér betegségben, valamint a szövődményes szívelégtelenségben szenvedő betegeknél is [3].

A kardiológiai rehabilitáció során törekedni kell arra, hogy a betegeket viszszavezessük az aktív életvitelükhöz és megakadályozzuk egy újabb kardiovaszkuláris esemény kialakulását. Az egyénre szabott fizikai tréning program, a tervezett, strukturált és ismétlődő testmozgás, a fizikai erőnlét fenntartását és fejlesztését szolgálja. A tréningprogramot megelözően javasolt a tünethatárolt terheléses vizsgálat elvégzése. A terheléses vizsgálat eredményeinek magában kell foglalnia a szívfrekvenciát, a ritmust, a ST-szakasz változásait, a vérnyomás változását, a Borg-skála értékét, a klinikai tüneteket és a terhelhetőséget. $\mathrm{Ha}$ a terheléses vizsgálat nem kivitelezhetö, akkor a funkcionális kapacitást egyéb eszközökkel (pl. járásteszt, speci- fikus kérdőívek) jellemezhetjük. A beteg rizikó-stratifikációjával szerzett adatok alapján határozzuk meg, hogy milyen mértékü felügyeletet és monitorozást igényel a tréning alatt [4].

\section{A tréningprogram formái}

A kardiológiai rehabilitáció során alkalmazott mozgásprogramok és módszerek a légzőtorna, a rehabilitációs tornák (a hagyományos, az intervallum tréning), a külső ellenállás nélkül, valamint a külső ellenállással szemben végzett (intervallum-rezisztencia tréning), a kar-, nyak-, váll torna, az alsó végtagi intervallum tréning, valamint a mozgásszervi torna kardiológiai betegre adaptálva [5].

A rehabilitációs torna kedvező hatást gyakorol a szív-, ér- és mozgásrendszer állapotára, javítja az állóképességet és a teljesítményt, kedvezően befolyásolja a közérzetet, csökkenti a rizikófaktorokat (pl. a testsúlyt, a vér koleszterin és triglicerid szintjét, a pulzust, a vérnyomást), csökkenti a hirtelen halál vagy újabb infarktus kialakulásának kockázatát. A rehabilitációs torna a korai infarktusos és mütött betegeknél a kórteremben légzőtornával kezdődik. A légzőtorna kihat a szív munkájára és az egész vérkeringésre, befolyásolja a hasi szervek müködését, az emésztést, hatással van a vegetatív idegrendszer működésére. A légzőtorna célja a lehető legnagyobb mellkas tágulás elérése, a helytelen légzés és testtartás következtében túlerőltetett izmok lazítása, valamint nyújtása. A gyógytornász megbeszéli a beteggel az addig végzett torna menetét, erősségét, tájékozódik az esetleges társbetegségekről, megméri a beteg pulzusát, megtornáztatja az állapotától függően (fekve, ülve, állva), majd az eredményeket a kezelölapon rögzíti. A terhelhetöség következő fokozata a gyalogló teszt 
(100 m/perc=4 MET). 4 MET teljesítése a feltétele annak, hogy a beteg a tornateremben tornázhasson, kimehessen a szabadba [6].

A tornateremben különböző erősségü rehabilitációs tornák folynak:

- III. fokozatú (gyenge) csoport: azon betegek járnak ebbe a csoportba, akiknek teljesítőképessége 5 MET-nél alacsonyabb.

- II. fokozatú (közepes erősségü) csoport: a betegek teljesítménye 5-8 MET között van. Itt már ismert a beteg tréningpulzusa, amelyet az orvos a terheléses vizsgálat alapján tréninglapra rávezet. Ha ez még nem történt meg, ügyelni kell arra, hogy a pulzus a 120/percet ne haladja meg.

- I. fokozatú (erős, intenzív) csoport: a teljesítőképesség a 8 MET-et meghaladja [7].

Foglalkozások alatt a pulzusszámot az elöírt határok között kell tartani. Ez az úgynevezett tréningpulzus, amelynek alsó értéke a terheléses vizsgálatkor megállapított maximális pulzusszám 70\%-a, a felső érték pedig $85 \%$-a. A tréningpulzus (THR) Karvonen-módszerrel történő meghatározása a maradék pulzus kiszámolásán alapszik. A maradék pulzus a nyugalmi pulzus és a maximális pulzus különbsége, ami direkt összefüggésben van a $\mathrm{VO}_{2}$ max-al: $\mathrm{THR}=(220$ - életkor - ébredési pulzus) x edzésintenzitás (0,6$0,8)+$ ébredési pulzus. A tréningpulzus felső értékének túllépése túlterhelést jelent, nem előnyös a szívbeteg számára. [8].

A hagyományos tréning három részből áll. A bemelegítés célja a keringésés mozgásszervi rendszer felkészítése a nagyobb terhelésre, az izmok, szalagok, izületek kilazítása, és megnyújtása és a véráramlás fokozása. Könnyü, lendületes feladatokkal minden nagyobb izomcsoport megmozgatása. Időtartama és intenzitása a csoportokhoz alkalmazkodik (pl. erős csoport esetén rövidebb és intenzívebb a bemelegítés, míg a gyengített csoportnál hosszabb és több légzőgyakorlatot tartalmaz). Jól megválasztott gyakorlatok esetén a bemelegítés végére a beteg tréningpulzusának alsó értékét kell megközelíteni. A tornát úgy alakítják, hogy a nagyobb izomcsoportok felváltva legyenek igénybe véve. Alkalmaznak gimnasztikai gyakorlatokat (eszközökkel változatossá téve: labdák (hagyományos, medicin), tornabotok, buzogányok, gumiszalagok), valamint játékokat: habtenisz, foci, tollaslabda stb.

A fokozatosság elvét betartva a könynyebb feladatok felől a nehezebb felé haladnak, az intenzitást fokozatosan növelik, a terhelés időtartamát naprólnapra percekkel elnyújthatják. A levezetés célja a terhelés során felhalmozódott anyagcseretermékek eltávolításának elősegítése, az izomláz megelőzése (könynyü, lazító gyakorlatok, sok nyújtózás, légzőgyakorlatok) [9].

$\mathrm{Az}$ intervallum tréning olyan edzésforma, amelyben magas intenzitású szakaszok váltakoznak alacsony intenzitású szakaszokkal (a magas intenzitású részek hosszabbak). Egyik formája a külső ellenállás alkalmazása nélkül végzett intervallum tréning, melynek során a nagyobb izomcsoportokat dinamikusan átmozgatják, 8-12-es ismétlésszámmal, majd 30-60 szekundumon keresztül légzőgyakorlatokat végez a beteg. Egy torna alkalmával minimum három intervallum valósul meg. A külső ellenállással vagy szabad súlyokkal szemben végzett intervallum tréning (intervallumokban végzett rezisztencia tréning) során kis súlyokkal történő egyéni izomerőre adaptált tréninget végeznek, szigorúan 
monitorozva (Polar-rendszer). Szívmütét és szívinfarktus után 6 hétig nem javasolt elkezdeni. Az intervallum tréning előnyeit képezi az, hogy változatossá teheti a kardiológiai rehabilitációt, csökkentheti a magas vérnyomást, fejleszthető vele a kollaterális érrendszer állapota, javulhat a szív pumpafunkciója [10].

A rehabilitációs tornák végén a betegek saját értékelését használják a terhelés nagyságának megállapítására. Ebben segít a Borg-skála, amely Prof. Dr. Gunnar Borg (Stockholm) által kifejlesztett értékelési eljárás a szubjektív terhelésérzet meghatározásához.

A testi igénybevétel során jelentkező szubjektív érzéseket 20 -as skálán ábrázolja (1. ábra).

\begin{tabular}{|l|r|}
\hline \multicolumn{2}{|c|}{ Borg-skála } \\
\hline nagyon-nagyon enyhe & $6-8$ \\
\hline nagyon enyhe & $9-10$ \\
\hline enyhe & $11-12$ \\
\hline kissé nehéz & $13-14$ \\
\hline nehéz & $15-16$ \\
\hline nagyon nehéz & $17-18$ \\
\hline nagyon-nagyon nehéz & $19-20$ \\
\hline
\end{tabular}

\section{1. ábra}

A rehabilitáció során segítik a betegeket az otthoni mozgásprogram kialakításában. Olyan mozgásformákat ajánlanak, amelynek ciklikusság az alapja: gyalogláskocogás-futás, kerékpározás, úszás, tenisz, evezés stb. Távozáskor célszerű a betegeket szakmai anyagokkal ellátni [11].

Testünk felső részének parányi meghibásodása is olyan tüneteket okozhat, mint például: fájdalom, zsibbadás, görcsös, merev izomzat, vérellátási zavarok, stb. Ezek megelőzésére, illetve a már kialakult tünetek enyhítésére nyújt lehetőséget a megfelelő mozgás, a kar- nyak-váll torna. A torna során az izomegyensúly helyreállítása, a görcsös és feszes izmok nyújtása, lazítása, a legyengült izmok erősítése, a vérkeringés javítása, a tüdőkapacitás növelése történik, a helyes ülésre és gerinctartásra hívja fel a figyelmet. A mozgásszervi betegségek napjainkban rendkívül elterjedtek, emiatt a betegeknél fájdalom, mozgáskorlátozottság léphet fel; testtartásuk, alakjuk egészen megváltozhat. A kialakult panaszok enyhítésére, a további problémák megelőzésére szolgál a mozgásszervi torna. A torna kíméletesen átmozgatja a főbb izületeket (különösen: a gerinc kisizületeit, csípőt, térdet). Fő célja a tartásjavítás, hát-, derék-, csípőkörüli, valamint hasizomzat erősítés, keringésjavítás. A feladatsorba sok lazító és légzőgyakorlatot iktatnak be [12].

$\mathrm{Az}$ alsó végtagi intervallum tréninget az alsó végtag artériás megbetegedéseinél a Fontaine szerinti beosztásnak megfelelő a II. stádiumban levő betegeknél alkalmazzák. Lényege a szűkülettől lejjebb (disztálisan) lévő nagy izomcsoportok szakaszokban történő edzése, amelynek mértékét az elvégzett funkcionális tesztek eredményére építik, az utóbbiak fontosak a keringés megítélésében, valamint a szükület helyére is következtetni engednek. Guggolási (térdhajlitási) teszt: 60/perc ütemben megszámolják, hogy a beteg a fájdalom jelentkezéséig hányszor tudja behajlítani a térdeit (ezt veszszük maximális teljesítménynek). Lábujjhegyre állási teszt: üteme szintén 60/ perc. Járatási próba: hosszú, sík folyosón (100 lépés/perc ütemben) kísérik a beteget, közben kérdezik a fájdalom kezdetéről; figyelik és rögzítik, hogy mikor kezdi meg az ún. kímélő járást; illetve mikor áll meg, vagyis felmérik a járástávolságát. A teszteknél kapott maximális eredmények kb. 70\%-ával terhelnek [13]. 
A Nordic Walking nem más, mint egy séta speciálisan megalkotott botokkal, amely az 1980-as évek végén indult Finnországból. Főbb hatásai közül kiemelendők az állóképesség javítása és a vérkeringés fokozása (a szívfrekvenciát percenként 5-15 dobbanással növeli a normál gyalogláshoz képest). Továbbiakban a Nordic Walkking csökkenti a testsúlyt (nagyobb a kalória felhasználás, mint sima gyaloglás esetén), kedvező hatással van a betegek pszichés állapotára, javítja a koordinációt, alkalmas a nyak-, váll- és vállövi izmok spazmusának, fájdalmának oldására. A botok megfelelö használata esetén kevésbé terheli a térd- és csípőizületeket, mint a normál gyaloglás, biztonságos gyaloglás érzését nyújtja [14].

A relaxációs módszerek közül leggyakrabban a Schultz-féle autogén tréninget alkalmazzák, melynek hatféle gyakorlatát (a nehézség- és melegségérzés, a szív, a légzés, a "hasmelegedés”, valamint a homlok hüvösségének gyakorlatát) csendes, nyugodt környezetben, általában matracon fekve, kellemes aláfestő zenére tanítják a betegeknek. A relaxációs tréning hatására csökken az izmok feszültségi állapota, javul a perifériás keringés, csökken a légzésszám, fokozódik a hasi szervek vérellátása, kedvezően befolyásolja a pulzust és a vérnyomást, segíthet a mindennapi stressz helyzetek megoldásában, elősegíti a kiegyensúlyozott mozgás kialakulását [15].

\section{Összegzés}

A rendszeres tréning a kardiológiai rehabilitáció kulcsfontosságú eleme a különböző szívbetegségekben szenvedőknél. A kardiológiai rehabilitáció során egyénre szabott rendszeres tréning ajánlott, mivel kedvező hatásai vannak a tü- netekre, a funkcionális kapacitásra, az élettani paraméterekre, a beteg közérzetére és a szívbetegség kimenetelére.

\section{Irodalom}

[1] Bjarnason-Wehrens, B., McGee, H., Zwisler, A.D.: Cardiac rehabilitation in Europe: Results from the European Cardiac Rehabilitation Inventory Survey. Eur. J. Cardiovasc. Prev. Rehabil., 2010, 17: 410-418. DOI: 10.1097/HJR.0b013e328334f42d.

[2] McCreery, C., Cradock, K., Fallon, N., et al.: Cardiac Rehabilitation Guidelines 2013, Dublin: Irish Association of Cardiac Rehabilitation. Available at: http://www.iacr.info/ about/guidelines/ (2013, accessed 24 March 2015).

[3] Turk-Adawi, K., Sarrafzadegan, N., Grace, S. L.: Global availability of cardiac rehabilitation. Nat. Rev. Cardiol., 2014, 11: 586-596.

DOI: $10.1038 /$ nrcardio.2014.98.

[4] Sandström, L., Ståhle, A.: Rehabilitation of elderly with coronary heart disease - Improvement in quality of life at a low cost. Adv. Physiother., 2009: 7: 60-66.

DOI: $10.1080 / 14038190510010287$.

[5] Anderson, L., Oldridge, N., Thompson, et al.: Exercise-based cardiac rehabilitation for coronary heart disease: Cochrane systematic review and meta-analysis. J. Am. Coll. Cardiol., 2016, 67: 1-12.

DOI: 10.1016/j.jacc.2015.10.044.

[6] Goel, K., Pack, Q. R., Lahr, B.: Cardiac rehabilitation is associated with reduced longterm mortality in patients undergoing combined heart valve and CABG surgery. Eur. J. Prev. Cardiol., 2015, 22: 159-168.

DOI: $10.1177 / 2047487313512219$.

[7] Marzolini, S., Oh, P.I, Brooks, D.: Effect of combined aerobic and resistance training versus aerobic training alone in individuals with coronary artery disease: A meta-analysis. Eur. J. Prev. Cardiol., 2012, 19: 81-94. DOI: $10.1177 / 1741826710393197$.

[8] Pavy, B., Iliou, M.C., Verges-Patois, B.: French Society of Cardiology guidelines for 
cardiac rehabilitation in adults. Arch. Cardiovasc. Dis., 2012, 105: 309-328.

DOI: 10.1016/j.acvd.2012.01.010.

[9] World Health Organization. Global Recommendations on Physical Activity for Health. Geneva: World Health Organization. Available at: http://www.who.int/diet physicalactivity/factsheet_recommenda tions/en/ (2010, accessed 29 April 2015).

[10] Maddison, R., Pfaeffli, L., Whittaker, R.A.: Mobile phone intervention increases physical activity in people with cardiovascular disease: Results from the HEART randomized controlled trial. Eur. J. Prev. Cardiol., 2015, 22: 701-709.

DOI: $10.1177 / 2047487314535076$.

[11] Pattyn, N., Vanhees, L., Cornelissen, V.A, et al.: The long-term effects of a randomized trial comparing aerobic interval versus continuous training in coronary artery disease patients: 1-year data from the SAINTEX-CAD study. Eur. J. Prev. Cardiol., 2016, 23: 1154-1164.

DOI: $10.1177 / 2047487316631200$.

[12] Achttien, R.J., Staal, J.B., van der Voort, S.: Exercise-based cardiac rehabilitation in patients with coronary heart disease: A practice guideline. Neth Heart J., 2013, 21: 429438. DOI: $10.1007 / \mathrm{s} 12471-013-0467-y$.

[13] McDermott, M. M.: Exercise rehabilitation for peripheral artery disease: a review. J. Cardiopulm. Rehabil. Prev., 2018, 38(2): 63-69. DOI: 10.1097/HCR.0000000000000343

[14] Girold, S., Rousseau, J., Le Gal M., Coudeyre, E., Le Henaff, J., Nordic walking versus walking without poles for rehabilitation with cardiovascular disease: Randomized controlled trial. Ann. Phys. Rehabil. Med., 2017, 60(4):223-229.

DOI: 10.1016/j.rehab.2016.12.004.
[15] Fletcher, G. F., Ades, P.A., Kligfield, P.: Exercise standards for testing and training: A scientific statement from the American Heart Association. Circulation, 2013, 128: 873-934.

DOI: 10.1161/CIR.0b013e31829b5b44

\section{Col. L. Kohut MDMC, PhD}

\section{Exercise training characteristics in cardiac rehabilitation}

Cardiovascular diseases are the leading cause of death globally. Physical activity was associated with significant reduction in all-cause mortality and reduction in current myocardial infarction. Cardiac rehabilitation/secondary prevention programs should contain specific core components that aim to optimize cardiovascular risk reduction, foster healthy behaviors and compliance to these behaviors, reduce disability, and promote an active lifestyle for patients with cardiovascular disease. Meta-analyses have shown a powerful association between physical activity counselling/exercise training and major health outcomes.

Key-words: coronary heart disease, cardiac rehabilitation and exercise training, cardiorespiratory fitness

Dr. Kohut László o.ezds., PhD 1134 Budapest, Róbert Károly krt. 44. 